\title{
Hubungan antara Asupan Asam Lemak Tidak Jenuh Ganda pada Ibu Menyusui, Kandungannya dalam ASI dan Lingkar Kepala Bayi: Studi pada Periode Awal Postpartum
}

\section{Association between Polyunsaturated Fatty Acid Intake in Lactating Women, Their Content in Breast Milk and Infant Head Circumference: Study in the Early Postpartum Period}

\author{
Muti'ah Mustaqimatusy Syahadah ${ }^{*}{ }^{1}$, Mira Dewi ${ }^{1}$, Rimbawan Rimbawan ${ }^{1}$
}

\begin{abstract}
ABSTRAK
Latar Belakang: Tercukupinya kebutuhan asupan asam lemak tidak jenuh ganda (polyunsaturated fatty acids, PUFA) ibu menyusui diketahui memiliki peran penting dalam mendukung pertumbuhan dan perkembangan otakbayi. Peran asupan PUFA ibu menyusui dalam mendukung tumbuh kembang bayi adalah melalui perantara ASI. ASI merupakan sumber utama zat gizi bayi baru lahir, salah satunya adalah PUFA. Studi menunjukkan bahwa asupan PUFA ibu menyusui di Kota Bogor masih sangat rendah terutama EPA dan DHA. Rendahnya asupan PUFA ibu menyusui diduga berpengaruh terhadap pertumbuhan otak bayi yang dalam penelitian ini diestimasi dengan ukuran lingkar kepala.

Tujuan: Penelitian ini bertujuan menganalisis hubungan asupan PUFA ibu menyusui dengan kandungan PUFA ASI dan lingkar kepala bayi baru lahir.

Metode: Analisis data sekunder menggunakan data hasil penelitian hibah BASF South East Asia yang telah dilakukan pada bulan April-Oktober tahun 2018 di Kota Bogor oleh tim SEAFAST CENTER IPB. Subyek merupakan ibu ibu menyusui berusia 18-45 tahun yang melahirkan bayi tunggal. Total terdapat 79 data ibu dan bayinya yang meliputi data asupan PUFA saat menyusui , kandungan PUFA ASI, lingkar kepala bayi, karakteristik ibu dan bayinya, kondisi sosial-ekonomi ibu, dan IMT prahamil. Analisis data dilakukan menggunakan uji korelasi Spearman.

Hasil: Rata-rata asupan PUFA ibu saat menyusui tergolong rendah ( $<80 \%$ tingkat kecukupan) serta belum memenuhi rekomendasi asupan PUFA. Asupan LA ibu berhubungan signifikan positif dengan kandungan LA ASI ( $p=0,012)$, sedangkan asupan ALA ibu memiliki hubungan signifikan negatif dengan kandungan ALA ASI $(p=0,027)$. Lingkar kepala bayi tidak berhubungan signifikan dengan asupan ibu saat menyusui dan kandungan PUFA ASI $(p>0,05)$.

Kesimpulan: Asupan PUFA ibu menyusui tidak berhubungan dengan kandungan PUFA ASI dan lingkar kepala bayi.
\end{abstract}

Kata kunci: Air Susu Ibu (ASI), Asam Lemak Tidak Jenuh Ganda, Ibu Menyusui , Lingkar Kepala Bayi

\section{ABSTRACT}

Background: Meeting the need of polyunsaturated fatty acids (PUFA) for lactating women is known to play an important role in supporting the infant brain growth and development. The role of lactating women PUFA intake in supporting infant growth and development is through breastfeeding. Breast milk is the main source of nutrients for infant, such as PUFA. A previous study showed that the PUFA intake of lactating women in Bogor was very low, especially EPA and DHA. . The low intake of PUFA in lactating women may affect infant brain growth which in this study was estimated using head circumference. Objective: This study aims to analyze the association between PUFA intake of lactating women with breast milk PUFA and infant head circumference.

Methods: Secondary data analysis methods used data from BASF South East Asia grant research conducted on April-October 2018 in Bogor City by SEAFAST CENTER IPB team. Subjects were lactating women aged 18-45 years who delivery a singleton baby. A total of 79 data mothers and their babies included data on PUFA intake during during lactation, breast milk PUFA, infant head circumference, maternal and infant characteristics, maternal socioeconomic status, and pre-pregnancy BMI. Data analysis was performed using the Spearman correlation test.

Results: The mean maternal PUFA intake during lactation was low (< $80 \%$ adequacy level) and had not met the recommendations of PUFA intake. Maternal LA intake was positively significant associated with breast milk $L A(p=0.012)$, while maternal ALA intake had a significant negative correlation with breast milk ALA ( $p=0.027)$. Infant head circumference was not significantly associated with maternal intake duting lactation and breast milk PUFA ( $p=0.05)$.

Conclusion: The PUFA intake of lactating women was not related to the breast milk PUFA and the infant head circumference.

(C)2021. Syahadah, et.al. Open access under CC BY - SA license.

Received: 20-10-2020, Accepted: 22-03-2021, Published online: 01-09-2021.

doi: 10.20473/amnt.v5i3.2021. 292-302. Joinly Published by IAGIKMI \& Universitas Airlangga 
Keywords: Breast Milk, Infant Head Circumference, Lactating Women, Polyunsaturated Fatty Acids (PUFA)

\author{
*Korespondensi: \\ mutiahms2411@gmail.com \\ Muti'ah Mustaqimatusy Syahadah \\ ${ }^{1}$ Departemen Gizi Masyarakat, Fakultas Ekologi Manusia, IPB University \\ Jl. Raya Dramaga, Kec. Dramaga, 16680, Kab. Bogor, Jawa Barat, Indonesia \\ Diterbitkan Oleh Universitas Airlangga dan IAGIKMI
}

\section{PENDAHULUAN}

Selain sebagai sumber energi, asam lemak memiliki peranan penting dalam proses pertumbuhan dan perkembangan bayi. Asam lemak tak jenuh ganda atau polyunsaturated fatty acids (PUFA) terdiri atas linoleic acids (LA) yang dikenal dengan omega- $6(n-6)$ dan alpha-linolenic acids (ALA) yang dikenal dengan omega-3 $(\mathrm{n}-3)$. Turunan PUFA adalah long chain-PUFA (LC-PUFA) dimana LC-PUFA $n-3$ adalah EPA (eicosapentaeonic acid) dan DHA (docosahexaenoic acid), sedangkan LC-PUFA n-6 adalah ARA (arachidonic acid). Omega-3 dan omega-6 dikategorikan sebagai asam lemak esensial karena tidak bisa diproduksi oleh tubuh sehingga harus dipenuhi dari asupan bahan pangan sumber $n-3$ dan n-6. PUFA dan LCPUFA berperan penting dalam proses tumbuh kembang bayi ${ }^{1,2}$. Pada usia kehamilan trimester 3 hingga anak berusia 2 tahun, janin/bayi mengalami pertumbuhan dan perkembangan pesat (growth spurt). Pada periode tersebut, terjadi proses akumulasi LC-PUFA pada sistem saraf pusat bagian otak dan retina sehingga suplai LCPUFA ke janin/bayi harus terpenuhi ${ }^{3,4}$.

Asupan PUFA ibu menyusui dapat berpengaruh pada pertumbuhan dan perkembangan bayi, yakni salah satunya pada pertumbuhan lingkar kepala bayi. Asupan ibu menyusui memiliki pengaruh tidak langsung pada pertumbuhan dan perkembangan otak yang dapat dilihat dari pertumbuhan lingkar kepala bayi. Pengaruh tidak langsung tersebut melalui perantara ASI. Asupan PUFA ibu akan dapat memengaruhi kualitas PUFA ASI. Suplai utama PUFA bagi bayi usia 0-6 bulan adalah kandungan PUFA pada ASI sehingga jika kualitas PUFA ASI baik maka bayi dapat memenuhi kebutuhan PUFA untuk menunjang tumbuh kembang otak yang optimal ${ }^{5,6}$.

Lingkar kepala bayi dapat digunakan sebagai indikator untuk memprediksi pertumbuhan otak dan perkembangan kognitif bayi. Lingkar kepala adalah refleksi ukuran tulang tengkorak, terutama rongga intrakranial, dimana otak berada ${ }^{4}$. Pada kondisi nonpatologis, semakin cepat dan optimal proses pertumbuhan dan perkembangan otak bayi maka semakin besar ukuran lingkar kepala bayi. Beberapa faktor yang dapat memengaruhi ukuran lingkar kepala bayi adalah karakteristik ibu, kondisi sosial-ekonomi, status gizi ibu, dan asupan zat gizi ibu ${ }^{7-9}$. Bayi dengan ukuran lingkar kepala yang lebih besar diketahui memiliki IQ lebih tinggi saat berusia 9-10 tahun ${ }^{10}$ dan saat remaja ${ }^{11}$. Penelitian Lauritzen et al. ${ }^{12}$ dan Bernard et al. ${ }^{13}$ menyebutkan bahwa bayi yang mengonsumsi ASI tinggi DHA memiliki akumulasi DHA lebih banyak pada otak. Tingginya akumulasi DHA pada otak juga diikuti dengan pertumbuhan otak yang lebih cepat dan kemampuan kognitif yang lebih baik.

ASI merupakan sumber utama PUFA bagi bayi baru lahir, terutama pada periode ASI eksklusif (0-6 bulan). Selain itu, ASI juga mengandung zat gizi yang optimal untuk menunjang tumbuh kembang bayi ${ }^{14,15}$. Penelitian yang dilakukan di beberapa kabupaten/kota di Indonesia menunjukkan bahwa kandungan PUFA ASI di Indonesia adalah 3,96-7,48\% untuk LA, 0,18-0,3\% untuk ALA, 0,04-0,05\% untuk EPA, 0,18-0,21\% untuk DHA, dan 0,09-0,13\% untuk ARA ${ }^{16}$. Kandungan PUFA ASI diketahui memiliki korelasi dengan asupan PUFA ibu menyusui ${ }^{17}$. Penelitian menunjukkan bahwa asupan PUFA ibu saat menyusui memiliki hubungan positif yang signifikan dengan kandungan PUFA ASI, terutama EPA dan DHA ${ }^{18-}$ ${ }^{20}$.Penelitian di Indonesia menunjukkan bahwa asupan PUFA ibu menyusui masih tergolong rendah. Hasil penelitian di Kota Bogor menunjukkan bahwa asupan ALA, EPA, dan DHA ibu menyusui masih belum memenuhi rekomendasi menurut Food and Agriculture Organization (FAO). Asupan PUFA ibu menyusui di Kota Bogor yakni sebesar $1,0 \mathrm{~g}$ ALA (0,4\% energi), 2,0 mg EPA, dan 0,7 mg DHA per hari ${ }^{21}$. Rekomendasi asupan per hari menurut FAO adalah 0,5-2\% energi untuk ALA, 100 mg untuk EPA, dan $200 \mathrm{mg}$ untuk DHA. Penelitian di negara lain menunjukkan hasil serupa dimana ibu menyusui di Korea Selatan memiliki asupan PUFA yang masih tergolong rendah dan belum dapat memenuhi rekomendasi ${ }^{20}$

Di Indonesia, belum banyak studi yang mengkaji hubungan asupan PUFA ibu menyusui dengan kandungan PUFA ASI dan lingkar kepala bayi dimana lingkar kepla bayi merupakan indikator pertumbuhan otak dan perkembangan kognitif. Tujuan penelitian ini adalah untuk menganalisis hubungan antara asupan PUFA ibu menyusui dengan kandungan PUFA ASI dan ukuran lingkar kepala bayi yang mengambil lokasi di Kota Bogor. Diharapkan hasil dari penelitian ini dapat menjadi dasar penyusunan strategi gizi ibu menyusui sebagai usaha untuk mencapai kesehatan dan kualitas bayi yang optimal di Indonesia.

\section{METODE}

Penelitian ini antara lain menggunakan data dari penelitian observasional yang mempelajari hubungan antara asupan PUFA, kadar PUFA darah ibu, dan kadar PUFA dalam ASI dengan komposisi tubuh bayi baru lahir yang disponsori oleh BASF South East Asia dan telah dilaksanakan pada tahun 2018 oleh tim SEAFAST CENTER IPB (studi PUFA BASF-SEAFAST IPB). Penelitian dilakukan di wilayah Puskesmas Bogor Utara dan Puskesmas Tanah Sereal. Subyek penelitian PUFA BASF-SEAFAST IPB adalah 
ibu berusia 18-45 tahun dengan kehamilan tunggal dan dalam kondisi sehat. Subyek tidak diikutsertakan apabila memiliki penyakit kronis (diabetes, kanker, penyakit liver dan ginjal kronis), hipertensi, anemia dengan kadar $\mathrm{Hb}<$ $9 \mathrm{mg} / \mathrm{dL}$, dan janin memiliki kelainan pertumbuhan dan atau kelainan kongenital. Subyek direkrut pada saat usia kehamilan trimester 3 (32-40 minggu) dan diamati hingga bayi berusia maksimal 8 hari setelah lahir. Data yang digunakan pada penelitian ini meliputi karakteristik ibu, kondisi sosial-ekonomi ibu, IMT pra-hamil, dan asupan PUFA saat menyusui, dan kandungan PUFA ASI yang berasal dari data penelitian PUFA BASF-SEAFAST IPB serta pengukuran langsung lingkar kepala bayi. Data-data tersebut digunakan karena diduga dapat menjelaskan pengaruh asupan PUFA ibu saat menyusui terhadap kandungan PUFA ASI dan lingkar kepala bayi. Pengumpulan data dilakukan oleh tim peneliti studi PUFA BASF-SEAFAST IPB. Data diperoleh dalam bentuk entry file dan kemudian dilakukan pengecekan kelengkapan data setiap subyek. Setelah dicek ketersediaan data, terdapat 79 subyek yang memiliki data lengkap dan kemudian diikutsertakankan dalam analisis.

Data karakteristik ibu, kondisi sosial-ekonomi ibu, dan data asupan PUFA diperoleh melalui wawancara menggunakan kuesioner yang dibuat khusus (selfdeveloped questionnaire) untuk studi PUFA BASFSEAFAST IPB oleh tim peneliti. IMT pra-hamil dan riwayat kehamilan diperoleh dari catatan medis atau wawancara, sementara data lingkar kepala bayi diperoleh melalui pengukuran langsung. Data baseline yang digunakan pada penelitian ini adalah data karakteristik dan kondisi sosialekonomi ibu meliputi usia ibu, paritas, tingkat pendidikan ibu, pekerjaan ibu, pendapatan keluarga, dan status gizi sebelum hamil berupa indeks massa tubuh (IMT) prahamil. Data usia ibu disajikan dalam rata-rata \pm standar deviasi (SD) dimana hasil tersebut diperoleh dari perhitungan langsung dengan menggunakan data tanggal lahir ibu yang diperoleh melalui wawancara. Paritas ibu diperoleh dari catatan medis pada buku kesehatan ibu dan anak (KIA), jika tidak tersedia maka ditanyakan secara langsung jumlah anak yang dimiliki saat data diambil. Paritas dikategorikan menurut justifikasi penulis menjadi $<1$ dan $\geq 1$. Tingkat pendidikan diperoleh dari data kelas dan jenjang pendidikan terakhir yang ditempuh oleh ibu. Tingkat pendidikan ibu dikategorikan menjadi rendah $(\leq 9$ tahun) dan tinggi ( $>9$ tahun $)^{22}$. Pekerjaan ibu dikategorikan menjadi tidak bekerja (ibu rumah tangga) dan bekerja (wirausaha, karyawan kantor, karyawan pabrik, dan lain-lain) menurut justifikasi penulis. Pendapatan keluarga adalah pendapatan per bulan yang diperoleh keluarga subyek dan dikategorikan menjadi miskin ( $\leq$ 1.578.348) dan tidak miskin (> 1.578.348) menurut garis kemiskinan rumah tangga di Jawa Barat ${ }^{23}$. IMT pra-hamil diperoleh dari hasil perhitungan menggunakan data berat badan (BB) sebelum hamil yang diperoleh dari catatan medis (Buku KIA) atau wawancara lansung dan data tinggi badan (TB) ibu [IMT = BB dalam $\mathrm{kg} /(\mathrm{TB} \text { dalam meter })^{2}$ ]. IMT pra-hamil dikelompokan menjadi kurus $\left(<18,5 \mathrm{~kg} / \mathrm{m}^{2}\right)$, normal $\left(18,5-25 \mathrm{~kg} / \mathrm{m}^{2}\right)$, gemuk $\left(25,1-27 \mathrm{~kg} / \mathrm{m}^{2}\right)$, dan sangat gemuk $\left(>27 \mathrm{~kg} / \mathrm{m}^{2}\right)^{24}$.
Selain data asupan PUFA saat menyusui, data endline yang digunakan meliputi lama periode kehamilan, kandungan PUFA ASI, jenis kelamin bayi, dan ukuran lingkar kepala bayi. Data endline seperti asupan PUFA saat menyusui, sampel ASI, dan ukuran lingkar kepala bayi diambil saat hari ke 5-8 postpartum. Hal ini dasarkan pada pertimbangan teknis dimana waktu tersebut adalah waktu tercepat subyek bersedia dikunjungi setelah melahirkan. Lama periode kehamilan dan jenis kelamin bayi diperoleh dari cacatan medis. Jenis kelamin bayi dikategorikan menjadi laki-laki dan perempuan, sedangkan lama periode kehamilan disajikan dalam ratarata \pm SD. Lingkar kepala bayi diukur menggunakan pita meteran non-elastis pada hari ke 5-8 setelah melahirkan (postpartum) menurut prosedur Center for Disease Control and Prevention (CDC). Data lingkar kepala bayi dinyatakan dalam satuan $\mathrm{cm}$ dengan skala terkecil 0,1 cm. Ukuran lingkar kepala bayi dikelompokan menjadi kecil (< $33 \mathrm{~cm})$, normal $(33-37 \mathrm{~cm})$, dan besar $(>37 \mathrm{~cm})$ menurut Kemenkes ${ }^{25}$. Sampel ASI yang dianalisis diperoleh dengan cara mengumpulkan sampel ASI secara langsung sebanyak $5 \mathrm{cc}$ antara pukul 09.00 - 12.00 WIB (pagi menjelang siang hari). Sampel ASI dikumpulkan dari salah satu payudara ibu dengan cara memijat payudara ibu. Sampel ASI disimpan pada suhu kulkas $\left( \pm 4^{\circ} \mathrm{C}\right.$ ) selama 6 jam dan kemudian disimpan pada suhu $-20{ }^{\circ} \mathrm{C}$ sebelum akhirnya dianalisis di Laboratorium Kesehatan Daerah Provinsi DKI Jakarta. Kandungan PUFA ASI diperoleh dari data hasil analisis kandungan PUFA ASI menggunakan metode gas chromatography.

Data asupan PUFA ibu diperoleh dari wawancara menggunakan kuesioner food recall $1 \times 24$ jam pada hari ke 5-8 postpartum. Data asupan ibu menyusui diolah dengan cara mengalikan jumlah bahan pangan yang dikonsumsi (gram) dengan berat bahan pangan yang dapat dimakan (BDD) dan kandungan PUFA (LA, ALA, EPA, DHA, dan ARA) pada database kandungan PUFA bahan pangan. Jumlah PUFA yang dikonsumsi kemudian dikategorikan berdasarkan rekomendasi asupan PUFA untuk ibu menyusui , yakni $14 \mathrm{~g}$ LA , 1,3 g ALA ${ }^{26}, 100 \mathrm{mg}$ EPA, $200 \mathrm{mg} \mathrm{DHA}^{27}$, dan $150 \mathrm{mg}$ ARA $^{28}$ per hari. Data kandungan PUFA bahan pangan diperoleh dari Tabel Komposisi Asam Lemak Indonesia ${ }^{29}$, NUTTAB $2010^{30}$, dan AUSNUT 2011-1331.

Pengolahan data pada penelitian ini dilakukan dengan menggunakan Microsoft Excel. Analisis data secara statistik dilakukan menggunakan Statistical Program for Social Science (SPSS) version 16.0 for Windows. Hasil uji normalitas Kolmogorov-Smirnov menunjukkan bahwa data yang digunakan pada penelitian ini memiliki sebaran data yang tidak normal ( $p$ $<0,05$ ). Oleh karena itu, analisis bivariat dilakukan menggunakan uji Spearman untuk mengetahui hubungan antara asupan PUFA ibu menyusui dengan kandungan PUFA ASI dan lingkar kepala bayi. Studi PUFA BASFSEAFAST IPB telah memperoleh persetujuan etik dari Komisi Etik Penelitian yang Melibatkan Subyek Manusia LPPM IPB dengan Nomor: 041/IT3.KEPMSM-IPB/SK/2018. 


\section{HASIL DAN PEMBAHASAN}

Data karakteristik dan kondisi sosial-ekonomi ibu tercantum pada Tabel 1. Subyek pada penelitian ini memiliki rata-rata usia $28,92 \pm 5,91$ tahun. Rata-rata paritas ibu adalah 1,3 $\pm 1,15$ dengan sebaran data sebanyak $70,9 \%$ ibu pada penelitian ini sudah pernah melahirkan sebelumnya, sementara sisanya $29,1 \%$ merupakan ibu dengan kelahiran anak pertama. Selain itu, Tabel 1 juga menyajikan data outcome kehamilan berupa lama periode kehamilan dan data karakteristik bayi yang meliputi lama periode kehamilan, jenis kelamin, dan ukuran lingkar kepala.

Tabel 1. Karakteristik dan Kondisi Sosial-Ekonomi Ibu dan Bayi

\begin{tabular}{|c|c|c|}
\hline Variabel & $\mathbf{n}$ & $\%$ \\
\hline Usia Ibu (tahun) ${ }^{\mathrm{a}}$ & \multicolumn{2}{|c|}{$28,92 \pm 5,91$} \\
\hline \multicolumn{3}{|l|}{ Tingkat Pendidikan Ibu } \\
\hline Rendah ( $\leq 9$ tahun) & 37 & 46,8 \\
\hline Tinggi (> 9 tahun) & 42 & 53,2 \\
\hline \multicolumn{3}{|l|}{ Pekerjaan Ibu } \\
\hline Tidak bekerja/IRT & 61 & 77,2 \\
\hline Bekerja & 18 & 22,8 \\
\hline Pendapatan Keluarga (Rp) ${ }^{a}$ & \multicolumn{2}{|c|}{$2.917 .000 \pm 1.452 .000$} \\
\hline Miskin $(\leq 1.578 .348)$ & 18 & 22,8 \\
\hline Tidak miskin (> 1.578.348) & 61 & 77,2 \\
\hline Paritas $^{\mathrm{a}}$ & \multicolumn{2}{|c|}{$1,3 \pm 1,15$} \\
\hline$<1$ & 23 & 29,1 \\
\hline$\geq 1$ & 56 & 70,9 \\
\hline Status Gizi Pra-hamil $\left(\mathrm{kg} / \mathrm{m}^{2}\right)^{\mathrm{a}}$ & \multicolumn{2}{|c|}{$23,27 \pm 4,01$} \\
\hline Kurus $(<18,5)$ & 3 & 3,8 \\
\hline Normal $(18,5-25)$ & 51 & 64,6 \\
\hline Gemuk $(25,1-27)$ & 11 & 13,9 \\
\hline Sangat Gemuk (> 27) & 14 & 17,7 \\
\hline Lama Periode Kehamilan (minggu) a & \multicolumn{2}{|c|}{$39,30 \pm 1,18$} \\
\hline \multicolumn{3}{|l|}{ Jenis Kelamin } \\
\hline Laki-laki & 37 & 46,8 \\
\hline Perempuan & 42 & 53,2 \\
\hline Lingkar Kepala Bayi $(\mathrm{cm})^{\mathrm{a}}$ & \multicolumn{2}{|c|}{$34,35 \pm 1,41$} \\
\hline Kecil $(<33)$ & 8 & 10,1 \\
\hline Normal (33-37) & 71 & 89,9 \\
\hline Besar (> 37) & 0 & 0,0 \\
\hline
\end{tabular}

a Data disajikan dalam rata-rata \pm SD.

Tingkat pendidikan ibu dikategorikan menurut Badan Pengawasan Keuangan dan Pembangunan (BPKP) ${ }^{22}$ menjadi rendah ( $\leq 9$ tahun) dan tinggi ( $>9$ tahun) dimana pada penelitian ini terdapat $53,16 \%$ ibu dengan tingkat pendidikan tinggi dan sisanya $46,84 \%$ tergolong berpendidikan rendah. Meskipun sebagian besar ibu berpendidikan tinggi, namun hanya $22,8 \%$ ibu yang bekerja sedangkan sisanya merupakan ibu rumah tangga (IRT) atau tidak memiliki pekerjaan. Hal ini tidak sejalan dengan pernyataan penelitian sebelumnya dimana semakin tinggi pendidikan ibu maka semakin baik pekerjaan ibu ${ }^{32}$. Penelitian di Cina menyebutkan bahwa ibu dengan status pekerjaan yang lebih baik akan memiliki pendapatan keluarga yang lebih tinggi ${ }^{33}$. Namun status pekerjaan ibu tidak berpengaruh terhadap pendapatan keluarga subyek pada penelitian ini. Meskipun lebih banyak ibu yang tidak bekerja, namun sebagian besar keluarga subyek $(77,2 \%)$ tergolong sebagai keluarga tidak miskin. Sementara sisanya sebesar $22,8 \%$ keluarga ibu memiliki pendapatan keluarga yang tergolong rendah dan masuk dalam kategori keluarga miskin menurut BPS ${ }^{23}$. Meskipun sebagian besar ibu pada penelitian ini tergolong sebagai keluarga tidak miskin, namun asupan PUFA ibu belum dapat memenuhi rekomendasi ${ }^{26-28}$ dan masih tergolong sangat rendah karena belum dapat mencapai $80 \%$ tingkat kecukupan asupan PUFA (Tabel 2). Jika dilihat dari status gizi ibu sebelum hamil, sebagian besar ibu memiliki IMT pra-hamil yang tergolong normal $(64,6 \%)$. Namun, terdapat pula ibu dengan status gizi kurang $(3,8 \%)$ dan status gizi lebih yang mencakup gemuk dan sangat gemuk $(31,6 \%)$. Status gizi ibu dapat memengaruhi asupan PUFA ibu dimana asupan omega- 6 (LA) cenderung lebih tinggi dan asupan omega-3 (ALA, EPA, DHA) cenderung lebih rendah pada ibu dengan status gizi lebih ${ }^{34}$. Berdasarkan hasil olah data asupan PUFA yang diperoleh melalui food recall $1 \times 24$ jam, asupan PUFA ibu menyusui pada penelitian ini masih tergolong sangat rendah (Tabel 2). 
Tabel 2. Asupan dan Tingkat Kecukupan Harian PUFA Ibu Menyusui

\begin{tabular}{lccc}
\hline \multicolumn{1}{c}{ Asam Lemak } & Rekomendasi & Asupan & Tingkat Kecukupan (\%) \\
\hline LA (g) & 14 & $7,44 \pm 4,95$ & $53,17 \pm 35,36$ \\
ALA (g) & 1,3 & $0,57 \pm 0,47$ & $44,0 \pm 36,35$ \\
EPA (mg) & 100 & $20,30 \pm 137,8$ & $20,20 \pm 137,8$ \\
DHA (mg) & 200 & $19,74 \pm 122,3$ & $9,87 \pm 61,14$ \\
ARA (mg) & 150 & $6,51 \pm 14,58$ & $4,34 \pm 9,72$ \\
\hline
\end{tabular}

Data disajikan dalam rata-rata \pm SD. PUFA: Polyunsaturated fatty acids. LA: Linoleic acid. ALA: Alpha-linolenic acid. EPA: Eicosapentaeonic acid. DHA: Docosahexaenoic acid. ARA: Arachidonic acid.

Hasil penelitian terkait asupan PUFA ibu menyusui di berbagai negara sangat beragam, namun sebagian besar menunjukkan hasil serupa dimana ibu menyusui memiliki asupan PUFA yang tergolong rendah. Asupan LA dan ALA subyek pada penelitian ini lebih rendah jika dibandingkan dengan asupan LA dan ALA ibu menyusui di Korea Selatan dan Cina. Meskipun asupan PUFA ibu di Korea Selatan lebih tinggi, namun asupannya masih tergolong rendah dimana asupan LA $(<14 \mathrm{~g} /$ hari) dan asupan ALA ( $<1,3 \mathrm{~g} /$ hari) masih di bawah rekomendasi ${ }^{20}$. Berbeda dengan ibu menyusui di Korea Selatan dan penelitian ini, asupan LA dan ALA ibu menyusui di Cina tergolong tinggi dimana asupan LA sebesar 19,9 g/hari dan asupan ALA 3,1 g/hari. Tingginya asupan LA dan ALA ibu menyusui di Cina dikarenakan bahan pangan sumber LA (minyak kacang kedelai, sunflower oil, dan peanut oil) dan bahan sumber ALA (kacang kedelai dan sereal) biasa dikonsumsi oleh penduduk Cina termasuk ibu menyusui ${ }^{35}$.

Telur dan daging merupakan bahan pangan utama sumber ARA, sedangkan ikan dan seafood merupakan bahan pangan utama sumber EPA dan $\mathrm{DHA}^{3,36}$. Asupan LC-PUFA subyek pada penelitian ini meliputi EPA, DHA, dan ARA juga lebih rendah dari asupan LC-PUFA ibu menyusui di Korea Selatan. Tingginya asupan LC-PUFA EPA, DHA, dan ARA ibu menyusui di Korea Selatan dikarenakan tingginya kebiasaan konsumsi ikan, rumput laut, dan jenis protein hewani lainnya seperti daging merah. Meskipun kebiasaan konsumsi bahan pangan sumber LC-PUFA di Korea Selatan tergolong tinggi, namun jumlah yang dikonsumsi belum dapat memenuhi rekomendasi asupan LC-PUFA untuk ibu menyusui ${ }^{20}$. Jika dibandingkan dengan asupan LC-PUFA ibu menyusui di Cina, asupan DHA subyek penelitian ini lebih tinggi. Namun sebaliknya untuk asupan EPA dan ARA dimana ibu menyusui di Cina memiliki asupan EPA dan ARA yang lebih tinggi dari subyek pada penelitian ini. Asupan ARA ibu menyusui di Cina yang lebih tinggi dari ibu menyusui pada penelitian ini dikarenakan ibu di Cina biasa mengonsumsi telur (83,3 g/hari) serta daging, ikan, dan seafood (250 g/hari) dalam jumlah yang banyak. Meskipun pada kategori daging, ikan, dan seafood jumlah bahan pangan yang dikonsumsi tergolong tinggi, namun proporsi konsumsi ikan dan seafood sangatlah rendah sehingga asupan DHA ibu menyusui di Cina tergolong rendah bahkan lebih rendah dari asupan DHA subyek pada penelitian ini $^{35}$.

Asupan PUFA ibu menyusui diketahui memiliki korelasi kuat dengan kandungan PUFA pada $\mathrm{ASI}^{17-20}$. Pada penelitian ini, sampel ASI yang analisis tergolong sebagai ASI transisi. ASI transisi merupakan ASI yang diproduksi oleh kelenjar mammae pada saat hari ke 5-14 setelah bayi lahir (postpartum) ${ }^{37}$. Kandungan PUFA ASI transisi pada penelitian ini ditampilkan pada Tabel 3.

Tabel 3. Kandungan PUFA dalam ASI pada 5-8 Hari Postpartum

Jenis PUFA

\begin{tabular}{lc}
\hline LA & $17,82(7,44-36,38)$ \\
ALA & $1,28(0,59-26,07)$ \\
EPA & $2,63(1,56-4,22)$ \\
DHA & $0,28(0,19-0,53)$ \\
ARA & $0,25(0,07-0,86)$ \\
\hline
\end{tabular}

Data disajikan dalam median (IQR). PUFA = Polyunsaturated Fatty Acids. LA: Linoleic acid. ALA: Alpha-linolenic acid. EPA: Eicosapentaeonic acid. DHA: Docosahexaenoic acid. ARA: Arachidonic acid.

Jika dibandingkan dengan kandungan PUFA ASI transisi secara global menurut penelitian pooled data analysis yang dilakukan Floris et al. ${ }^{38}$, ASI pada penelitian ini mengandung LA, ALA, dan EPA yang lebih tinggi daripada kandungan LA (14,15 g/100 g lemak), ALA (0,95 $\mathrm{g} / 100 \mathrm{~g}$ lemak), dan EPA $(0,14 \mathrm{~g} / 100 \mathrm{~g}$ lemak) ASI transisi secara global. Namun untuk kandungan DHA dan ARA, ASI transisi secara global mengandung DHA $(0,46 \mathrm{~g} / 100 \mathrm{~g}$ lemak) dan ARA (0,65 g/100 g lemak) yang lebih tinggi dari kandungan ASI transisi pada penelitian ini. Salah satu faktor yang dapat memengaruhi kandungan PUFA ASI terutama kandungan LC-PUFA n-3 (EPA dan DHA) adalah faktor demografi atau daerah tempat tinggal. Hal ini dapat dilihat pada penelitian Urwin et al. ${ }^{37}$ terkait kandungan PUFA ASI di beberapa daerah di Cina, yaitu daerah pesisir, daerah sungai/danau, dan daerah daratan. Pada penelitian tersebut, kandungan DHA ASI secara signifikan lebih tinggi di daerah pesisir dan sungai/danau dibandingkan kandungan DHA ASI di daerah daratan. Kandungan EPA dan DHA ASI ibu di Cina secara signifikan lebih tinggi pada daerah pesisir. Ibu di daerah pesisir memiliki akses yang baik terhadap bahan pangan sumber 
EPA dan DHA, yakni ikan berlemak (salmon, tuna, makarel) dan seafood sehingga asupan EPA dan DHA secara signifikan lebih tinggi di daerah pesisir. Demografi mungkin menjadi salah satu faktor penyebab rendahnya asupan serta kandungan EPA dan DHA ASI yang rendah karena penelitian ini dilakukan di daerah yang jauh dari pesisir.

Kandungan PUFA ASI terutama LC-PUFA n-3 yaitu DHA pada ASI dilaporkan dapat merefleksikan asupan DHA ibu menyusui ${ }^{18-20}$. Hal tersebut menunjukkan bahwa asupan PUFA ibu menyusui dapat berpengaruh terhadap kandungan PUFA pada ASI. Hasil analisis korelasi menggunakan uji Spearman pada penelitian ini menunjukkan bahwa asupan LA dan ALA ibu menyusui memiliki korelasi yang signifikan dengan kandungan LA dan ALA ASI, namun tidak terdapat hubungan signifikan antara asupan LC-PUFA (EPA, DHA, dan ARA) dengan kandungan LC-PUFA ASI. Asupan LA ibu menyusui berkorelasi positif dengan kandungan LA ASI $(r=0,281 ; p$ $=0,012$ ), sedangkan asupan ALA ibu menyusui memiliki korelasi negatif dengan kandungan ALA ASI $(r=-0,249 ; p$ $=0,027$ ) (Tabel 4).

Rata-rata usia kehamilan saat bayi dilahirkan adalah $39,30 \pm 1,18$ minggu. Bayi yang dilahirkan pada penelitian ini 53,2\% adalah perempuan dan sisanya $46,8 \%$ bayi laki-laki. Lingkar kepala bayi pada penelitian ini dikategorikan berdasarkan Kemenkes ${ }^{25}$ dimana sebagian besar bayi $(89,9 \%)$ memiliki ukuran lingkar kepala normal (Tabel 1). Rata-rata ukuran lingkar kepala bayi pada penelitian adalah $34,35 \pm 1,41 \mathrm{~cm}$ yang tidak jauh berbeda dengan lingkar kepala bayi di Cina $(34,5 \pm 1 \mathrm{~cm})^{39}$, India $(34,5 \pm 1,8 \mathrm{~cm})^{40}$, dan Jepang $(34,0 \pm 2 \mathrm{~cm})^{41}$.

Pada penelitian ini terdapat 8 bayi $(10,1 \%)$ yang dilahirkan dengan lingkar kepala yang tergolong kecil (mikrosefali). Terdapat asumsi bahwa apabila ibu hamil saat usia masih tergolong muda $(<20$ tahun) maka memiliki risiko tinggi melahirkan bayi mikrosefali. Selain itu, penelitian di Malaysia menyebutkan bahwa ibu yang hamil pada usia $\geq 35$ tahun dapat meningkatkan risiko melahirkan bayi mikrosefali ${ }^{9}$. Penelitian lain di Swedia menyebutkan bahwa ibu hamil dengan usia 15-19 tahun memiliki risiko $14,3 \%$ lebih besar dan ibu berusia $\geq 36$ tahun berisiko $16,1 \%$ lebih besar melahirkan bayi dengan ukuran kepala kecil dibandingkan ibu dengan usia 20-35 tahun ${ }^{42}$. Namun, bayi yang lahir dengan lingkar kepala kecil pada penelitian ini bukan berasal dari kelompok ibu berusia $<20$ tahun maupun ibu berusia $>35$ tahun.

WHO menyatakan bahwa bayi dikategorikan mengalami mikrosefali jika memiliki ukuran lingkar kepala $<-2 \mathrm{SD}$ atau $<32 \mathrm{~cm}$ pada grafik ukuran lingkar kepala (grafik Nelhaus) ${ }^{43}$, sedangkan Kemenkes ${ }^{25}$ menyebutkan bahwa bayi dengan ukuran lingkar kepala $<33 \mathrm{~cm}$ tergolong mikrosefali. Sebanyak 6 dari 8 bayi yang mengalami mikrosefali. Sebanyak 6 dari 8 bayi yang mengalami mikrosefali berdasarkan cut off point Kemenkes pada penelitian ini memiliki ukuran lingkar kepala normal pada batas bawah yakni sekitar $32 \mathrm{~cm}$ jika didasarkan pada grafik Nelhaus. Sisanya sebanyak 2 bayi memiliki ukuran lingkar kepala tergolong mikrosefali menurut Kemenkes $(<33 \mathrm{~cm})$ dan menurut grafik ukuran lingkar kepala WHO $(<-2 \mathrm{SD})^{25,43}$. Meskipun demikian, 8 bayi $(10,1 \%)$ yang tergolong mikrosefali pada penelitian ini tidak memiliki masalah antropometri lain jika dilihat dari berat badan ( $\geq 2500$ gram) maupun panjang badan ( $\geq$ $48 \mathrm{~cm}$ ) (data tidak ditampilkan).

Kandungan PUFA ASI dapat berasal dari uptake PUFA di plasma darah dan hasil sintesis simpanan PUFA tubuh ibu dimana kedua proses tersebut sangat bergantung pada asupan PUFA ibu. PUFA tergolong sebagai asam lemak esensial yang harus dipenuhi dari asupan sehari-hari karena tubuh tidak dapat mensintesis PUFA. Asupan PUFA ibu akan bersirkulasi di darah (plasma darah) setelah proses metabolisme dan absorpsi. Selain itu, PUFA di plasma darah juga dapat berasal dari sintesis simpanan PUFA jaringan tubuh ibu. PUFA yang terdapat pada plasma darah akan diserap oleh kelenjar mammae sebagai salah satu komponen PUFA ASI. Kelenjar mammae juga memiliki simpanan PUFA yang nantinya akan disintesis sebagai salah satu komponen PUFA ASI. Mekanisme penyerapan PUFA oleh kelenjar mammae dari plasma darah dan sintesis simpanan PUFA kelenjar mammae saling melengkapi. Jika uptake PUFA dari plasma darah rendah maka sintesis PUFA di kelenjar mammae akan tinggi, dan sebaliknya. Hal ini terjadi untuk mempertahankan kualitas ASI yang disekresikan dan kualitas suplai PUFA bagi bayi agar dapat menunjang tumbuh kembang bayi secara optimal, terutama tumbuh kembang otak yang sangat bergantung pada suplai PUFA $^{5,6}$.

Asupan PUFA ibu juga diketahui memiliki hubungan dengan ukuran antropometri bayi, yakni lingkar kepala. Asupan PUFA ibu menyusui dapat memengaruhi ukuran lingkar kepala bayi melalui perantara ASI. Asupan PUFA ibu akan memengaruhi kandungan PUFA ASI dimana PUFA pada ASI inilah yang nantinya akan dikonsumsi oleh bayi baru lahir dan akan berpengaruh terhadap tumbuh kembang otak dan lingkar kepala bayi. Pada periode ASI eksklusif (0-6 bulan), bayi sangat bergantung pada ASI sebagai sumber utama zat gizi ${ }^{14,15}$. Kecukupan suplai PUFA dari ASI akan sangat berpengaruh pada tumbuh kembang otak bayi. Catena et al. ${ }^{4}$ dan Chang et al. ${ }^{44}$ menyatakan bahwa $60 \%$ komponen otak bayi adalah lipid. Sebanyak $25-30 \%$ berat otak adalah asam lemak omega-3 dan omega-6 dimana sebanyak $10 \%$ dari total asam lemak di otak adalah DHA. Apabila ASI mengandung PUFA yang cukup maka suplai PUFA bagi bayi dapat memenuhi kebutuhan PUFA untuk proses pertumbuhan dan perkembangan, terutama tumbuh kembang otak. Hal tersebut dikarenakan tumbuh kembang otak sangat bergantung pada jumlah PUFA, terutama LC-PUFA DHA dan ARA, yang terakumulasi di otak. Lingkar kepala bayi merupakan salah satu indikator yang dapat digunakan dalam mengukur pertumbuhan dan perkembangan otak bayi. Lingkar kepala merupakan refleksi dari ukuran tulang tengkorak dimana rongga tengkorak merupakan tempat otak berada. Bertambah besarnya ukuran lingkar kepala merupakan refleksi dari semakin besarnya volume intrakranial (volume rongga tengkorak) dan semakin besarnya ukuran otak ${ }^{4}$.

Hasil penelitian sebelumnya yang dilakukan di Brazil menunjukkan bahwa kandungan LA ASI memiliki hubungan signifikan dengan kebiasaan konsumsi pangan 
sumber LA, yakni minyak sayur terutama minyak kacang kedelai ${ }^{19}$. Hal ini sejalan dengan hasil penelitian ini dimana asupan LA ibu memiliki hubungan signifikan dengan kandungan LA ASI. Hubungan positif yang signifikan antara asupan LA ibu dengan kandungan LA ASI pada penelitian ini mungkin disebabkan oleh tingginya kebiasaan konsumsi minyak kelapa sawit dan olahan kacang kedelai seperti tahu dan tempe. Minyak kelapa sawit dan kacang kedelai merupakan bahan pangan sumber LA dimana kandungan LA minyak kelapa sawit sebesar 9,0 g dan kandungan LA kacang kedelai sebesar 10,99 g per 100 g bahan $^{45}$. Pada penelitian ini, konsumsi tempe dan tahu serta bahan pangan yang diolah secara digoreng sangatlah tinggi. Hal ini mungkin menjadi salah satu penyebab signifikannya hubungan asupan LA dan kandungan LA ASI.

Meskipun asupan PUFA ibu pada penelitian ini tergolong sangat rendah, namun kandungan PUFA ASI tergolong tinggi untuk LA, ALA, dan EPA. Hal ini mungkin dikarenakan adanya proses pemecahan simpanan asam lemak tubuh ibu dan proses biosintesis LC-PUFA. Menurut Brenna dan Lapillonne ${ }^{46}$ dan Catalano dan Demouzon ${ }^{47}$, selama periode awal kehamilan tubuh ibu memiliki kemampuan lebih tinggi dalam menyimpan asam lemak. Simpanan asam lemak tersebut nantinya akan dipecah dan digunakan untuk menunjang tumbuh kembang janin saat periode akhir kehamilan dan untuk produksi ASI di awal masa postpartum (kolostrum dan ASI transisi). Simpanan asam lemak berupa LA dan ALA nantinya juga dapat digunakan sebagai prekursor dalam proses biosintesis EPA, DHA, dan ARA. Pada proses biosintesis LCPUFA, LA dapat dikonversi menjadi ARA sedangkan ALA dapat dikonversi menjadi EPA dan $\mathrm{DHA}^{48,49}$.

Hubungan negatif yang signifikan antara asupan ALA ibu dengan kandungan ALA ASI mungkin dikarenakan adanya proses biosintesis LC-PUFA n-3, yakni EPA dan DHA. Hasil menunjukan bahwa semakin tinggi asupan ALA ibu maka kandungan ALA ASI semakin rendah. Hal ini mungkin dikarenakan ALA yang dikonsumsi ibu akan lebih diutamakan oleh tubuh ibu untuk proses biosintesis EPA dan DHA, dimana kebutuhan DHA bayi sangat tinggi pada saat periode pertumbuhan dan perkembangan pesat otak. Proses biosintesis ALA menjadi EPA dan DHA terjadi apabila asupan dan simpanan EPA dan DHA tubuh ibu rendah. Tubuh ibu akan berusaha untuk mempertahankan kualitas ASI, dimana dalam hal ini EPA dan DHA, agar kebutuhan EPA dan DHA bayi terpenuhi dan dapat optimal menunjang proses tumbuh kembang bayi ${ }^{48,50}$. Namun, pada penelitian ini kandungan DHA ASI tergolong rendah dimana asupan DHA juga rendah. Berbeda dengan DHA, meskipun ibu memiliki asupan EPA yang rendah namun kandungan EPA ASI tergolong tinggi. Hal ini menunjukkan bahwa biosintesis DHA di kelenjar mammae tidak seoptimal proses biosintesis EPA. Antonakou et al. ${ }^{51}$ menyatakan bahwa apabila kandungan DHA ASI tinggi maka kandungan EPA ASI akan rendah dan sebaliknya.

Proses biosintesis LC-PUFA (EPA, DHA, dan ARA) sangat bergantung pada aktivitas enzim $\Delta-5$ dan $\Delta-6$ desaturase. Samanya jenis enzim yang digunakan menyebabkan adanya kompetisi antara LA dan ALA dalam proses konversi LA menjadi ARA dan proses konversi ALA menjadi EPA serta konversi EPA menjadi DHA. Biosintesis ARA terjadi ketika LA mengalami proses desaturasi dan elongasi. Hal yang sama juga terjadi pada ALA dalam proses biosintesis EPA dan DHA. ALA akan melalui tahapan desaturasi dan elongasi agar dapat diubah menjadi EPA, kemudian EPA akan mengalami desaturasi dan elongasi untuk dapat diubah menjadi $\mathrm{DHA}^{48-50}$. Tingginya biosintesis EPA di kelenjar mammae mungkin mengakibatkan rendahnya suplai enzim $\Delta-5$ dan $\Delta-6$ desaturase dalam proses biosintesis ARA dan DHA. Hal ini mungkin menjadi penyebab rendahnya kandungan DHA dan ARA pada ASI di penelitian ini.

Tabel 4. Hubungan antara Asupan PUFA Ibu Menyusui, Kandungan PUFA ASI, dan Lingkar Kepala Bayi

\begin{tabular}{lcccc}
\hline \multirow{2}{*}{ Asupan PUFA } & \multicolumn{2}{c}{ Kandungan PUFA ASI } & \multicolumn{2}{c}{ Lingkar Kepala Bayi } \\
\cline { 2 - 5 } LA & $\boldsymbol{r}$ & $\boldsymbol{p}$ value & $\boldsymbol{r}$ & $\boldsymbol{p}$ value \\
ALA & 0,281 & $0,012^{*}$ & $-0,111$ & 0,330 \\
EPA & $-0,249$ & $0,027^{*}$ & $-0,075$ & 0,511 \\
DHA & $-0,094$ & 0,411 & $-0,197$ & 0,081 \\
ARA & 0,034 & 0,763 & $-0,176$ & 0,121 \\
\end{tabular}

Uji korelasi Spearman. $r$ : koefisien korelasi. ${ }^{*}$ signifikan jika $\mathrm{p}<0,05$. PUFA = Polyunsaturated Fatty Acids. LA: Linoleic acid. ALA: Alpha-linolenic acid. EPA: Eicosapentaeonic acid. DHA: Docosahexaenoic acid. ARA: Arachidonic acid.

Hasil analisis uji hubungan pada Tabel 4 menunjukkan bahwa tidak terdapat hubungan signifikan antara asupan PUFA ibu menyusui dengan ukuran lingkar kepala bayi $(p>0,05)$. Hasil ini sejalan dengan penelitian Marc et al. di Kanada ${ }^{52}$ dan penelitian Collins et al. di Australia ${ }^{53}$. Pada penelitian tersebut, suplementasi DHA pada ibu menyusui tidak berpengaruh signifikan terhadap lingkar kepala bayi dimana ukuran lingkar kepala bayi kelompok intervensi dan kelompok kontrol tidak berbeda signifikan. Penelitian lain dengan metode meta-analisis menunjukkan bahwa hubungan signifikan antara suplementasi LC-PUFA ibu menyusui dengan lingkar kepala bayi baru terlihat saat bayi berusia 12 bulan $^{54}$. Hasil analisis uji hubungan antara kandungan PUFA ASI dengan lingkar kepala bayi ditampilkan pada Tabel 5 .

Hasil analisis pada Tabel 5 menunjukkan bahwa pada penelitian ini tidak terdapat hubungan yang signifikan antara kandungan PUFA ASI dengan ukuran lingkar kepala bayi. Hasil ini sejalan dengan penelitian Meldrum et al. ${ }^{55}$ di Australia dimana pada penelitian tersebut kandungan LC-PUFA ASI dilaporkan memiliki hubungan signifikan dengan status LC-PUFA bayi namun tidak berhubungan signifikan dengan lingkar kepala bayi. Penelitian eksperimental dengan melakukan fortifikasi 
LC-PUFA pada susu formula menunjukkan bahwa kandungan LC-PUFA yang tinggi pada susu formula tidak berpengaruh signifikan terhadap ukuran lingkar kepala bayi ${ }^{56-58}$

Tabel 5. Hubungan Kandungan PUFA ASI dengan Lingkar Kepala Bay

\begin{tabular}{lcc}
\hline \multirow{2}{*}{ Kandungan PUFA ASI } & \multicolumn{2}{c}{ Lingkar Kepala Bayi } \\
\cline { 2 - 3 } & $\mathbf{r}$ & $\boldsymbol{p}$ value \\
\hline LA & 0,041 & 0,721 \\
EPA & $-0,063$ & 0,583 \\
DHA & 0,108 & 0,345 \\
ARA & 0,079 & 0,487 \\
\hline
\end{tabular}

Uji korelasi Spearman. $r$ : koefisien korelasi. ${ }^{*}$ signifikan jika $\mathrm{p}<0,05$. PUFA = Polyunsaturated Fatty Acids. LA: Linoleic acid. ALA: Alpha-linolenic acid. EPA: Eicosapentaeonic acid. DHA: Docosahexaenoic acid. ARA: Arachidonic acid.

DHA dan ARA adalah jenis LC-PUFA yang berperan penting dalam proses pertumbuhan dan perkembangan otak bayi ${ }^{4}$. Pada penelitian ini, meskipun kandungan DHA dan ARA pada ASI tergolong rendah namun rata-rata ukuran lingkar kepala bayi tergolong normal. Hal ini menunjukkan bahwa kandungan PUFA ASI tidak berpengaruh kuat terhadap ukuran lingkar kepala bayi periode awal postnatal. Kemungkinan bayi memiliki kemampuan untuk mengonversi LC-PUFA dari kandungan LA dan ALA ASI yang tergolong tinggi. Glaser et al. ${ }^{48}$ dan Heaton et al..$^{59}$ menyatakan bahwa tubuh bayi memiliki kemampuan yang sama dengan tubuh ibu untuk mengonversi LA dan ALA menjadi LC-PUFA EPA, DHA, dan ARA. Hal tersebut dilakukan bayi agar kebutuhan LC-PUFA dapat terpenuhi untuk menunjang tumbuh kembang otak. Penelitian lain menyebutkan bahwa variasi genetik dalam proses metabolisme PUFA memiliki pengaruh besar terhadap perkembangan otak bayi dibandingkan tingginya kandungan LC-PUFA pada ASI ${ }^{60}$.

Tidak signifikannya hubungan asupan PUFA ibu menyusui dan kandungan PUFA ASI dengan ukuran lingkar kepala bayi mungkin dikarenakan data dikumpulkan terlalu cepat, yaitu saat hari ke 5-8 postpartum. Pada saat 5-8 hari postpartum, kemungkinan terjadinya bias dengan asupan PUFA dan simpanan PUFA ibu saat hamil sangatlah tinggi. Hal tersebut mengakibatkan hubungan asupan PUFA ibu menyusui dengan lingkar kepala bayi kurang akurat. Selain itu, kandungan PUFA ASI saat hari ke 5-8 postpartum atau ASI transisi masih dipengaruhi oleh asupan dan simpanan PUFA ibu saat hamil sehingga hubungan kandungan PUFA ASI dengan asupan PUFA ibu menyusui dan lingkar kepala bayi kurang akurat.

Ukuran lingkar kepala bayi dapat dipengaruhi oleh berbagai macam faktor seperti karakteristik ibu (usia ibu, usia kehamilan, paritas), kondisi sosial-ekonomi (pendidikan, pekerjaan, pendapatan), etnis, asupan zat gizi dan status gizi ibu (berat badan (BB), tinggi badan (TB), indeks massa tubuh (IMT) $)^{7-9}$. Pada penelitian ini, faktor-faktor tersebut tidak memiliki pengaruh signifikan $(p>0,05)$ atau bukan merupakan prediktor kuat ukuran lingkar kepala bayi saat dilakukan analisis multivariat menggunakan metode regresi logistik (data tidak ditampilkan). Namun, status gizi ibu yakni IMT pra-hamil memiliki hubungan signifikan dengan ukuran lingkar kepala bayi saat dilakukan analisis bivariat menggunakan uji Spearman ( $p=0,010)$ (data tidak ditampilkan).
Simpanan PUFA tubuh ibu dapat dilihat melalui indikator IMT dimana pada penelitian ini simpanan PUFA ibu dilihat dari data IMT pra-hamil. Hubungan IMT pra-hamil dengan lingkar kepala bayi adalah linear-up, namun pada titik tertentu kekuatan hubungannya akan menurun dan menjadi tidak signifikan. IMT pra-hamil berhubungan signifikan dengan lingkar kepala bayi, namun setelah IMT pra-hamil $21,5-22 \mathrm{~kg} / \mathrm{m}^{2}$ hubungan akan melemah dan menjadi tidak signifikan ${ }^{61}$. Hubungan yang signifikan antara IMT pra-hamil dengan lingkar kepala bayi pada penelitian ini dilihat secara umum tanpa mengelompokkan IMT pra-hamil sesuai kategori status gizi sehingga perlu hati-hati dalam menginterpretasikan hasil yang diperoleh.

Kelemahan dari penelitian ini adalah tidak tersedianya data lingkar kepala bayi saat lahir sehingga pertambahan ukuran lingkar kepala saat usia 5-8 hari postpatum tidak dapat diamati. Berdasarkan penelitian sebelumnya, lingkar kepala bayi pada usia 1 bulan pertama mengalami pertumbuhan sebesar $6 \mathrm{~mm} / \mathrm{minggu}$ menurut Voss et al. ${ }^{62}$, sedangkan menurut Herba et al. ${ }^{57}$ pertumbuhan maksimal lingkar kepala bayi adalah 1,1 $\mathrm{mm} /$ hari. Selain itu, penelitian ini hanya melibatkan ibu yang tinggal di daerah kota yang jauh dari akses pangan sumber PUFA terutama EPA dan DHA sehingga hasil tidak dapat digeneralisasikan pada populasi ibu menyusui di Indonesia secara luas.

\section{KESIMPULAN}

Asupan PUFA ibu menyusui meliputi LA, ALA, EPA, DHA dan ARA masih belum dapat memenuhi rekomendasi dan tergolong sangat rendah. Asupan LA ibu menyusui berhubungan signifikan positif dengan kandungan LA ASI, sedangkan asupan ALA ibu menyusui memiliki hubungan negatif yang signifikan dengan kandungan ALA ASI. Rendahnya asupan PUFA ibu menyusui diduga karena kurangnya pemahaman ibu terkait pentingnya peranan PUFA pada periode pertumbuhan pesat.

\section{ACKNOWLEDGEMENTS}

Terimakasih penulis ucapkan kepada BASF South East Asia dan tim peneliti SEAFAST CENTER IPB yang telah memberikan izin untuk menggunakan sebagian data dari penelitian utama dengan judul "Association of Maternal Dietary Intake and Blood Level of Long Chain Poly-Unsaturated Fatty Acids in Pregnancy and Newborn 
Body Composition". Penulis juga mengucapkan terimakasih kepada pembimbing yang telah membimbing penulis dalam menyelesaikan penelitian dan penulisan artikel hasil penelitian.

\section{REFERENSI}

1. Calder, P. C. Functional Roles of Fatty Acids and Their Effects on Human Health. J. Parenter. Enter. Nutr. 39, 18S-32S (2015).

2. Moghadasian, M. H. \& Shahidi, F. Fatty Acids. International Encyclopedia of Public Health vol. 3 (Elsevier, 2016).

3. Brown, J. E. Nutrition Through the Life Cycle, 4th Ed. Fluoride (Wadsworth Cengage Learning, 2011)

4. Catena, A. et al. On the relationship between head circumference, brain size, prenatal longchain PUFA/5-methyltetrahydrofolate supplementation and cognitive abilities during childhood. Br. J. Nutr. 122, S40-S48 (2019).

5. Innis, S. M. Impact of maternal diet on human milk composition and neurological development of infants. Am. J. Clin. Nutr. 99, 734-741 (2014).

6. Innis, S. M. Maternal Nutrition, Genetics, and Human Milk Lipids. Curr. Nutr. Rep. 2, 151-158 (2013).

7. Anindya, I. G., Salimo, H. \& Retno Dewi, Y. L. Hubungan Pemberian Asi Eksklusif Dan Status Gizi Ibu Dengan Pertumbuhan Lingkar Kepala Bayi Usia 6 Bulan. Amerta Nutr. 3, 263 (2019).

8. Silva, L. M. et al. Mother's educational level and fetal growth: The genesis of health inequalities. Int. J. Epidemiol. 39, 1250-1261 (2010).

9. Sutan, R. et al. Trend of head circumference as a predictor of microcephaly among term infants born at a regional center in Malaysia between 2011-2015. Res. Reports Neonatol. 8, 9-17 (2018).

10. Veena, S. R. et al. Higher maternal plasma folate but not vitamin B-12 concentrations during pregnancy are associated with better cognitive function scores in 9- to 10 - year-old children in South India. J. Nutr. 140, 1014-1022 (2010).

11. Jensen, R. B., Juul, A., Larsen, T., Mortensen, E. L. $\&$ Greisen, G. Cognitive ability in adolescents born small for gestational age: Associations with fetal growth velocity, head circumference and postnatal growth. Early Hum. Dev. 91, 755-760 (2015).

12. Lauritzen, L. et al. DHA effects in brain development and function. Nutrients 8, 1-17 (2016).

13. Bernard, J. Y. et al. Breastfeeding, Polyunsaturated Fatty Acid Levels in Colostrum and Child Intelligence Quotient at Age 5-6 Years. J. Pediatr. 183, 43-50.e3 (2017).

14. Eriksen, K. G., Christensen, S. H., Lind, M. V. \& Michaelsen, K. F. Human milk composition and infant growth. Curr. Opin. Clin. Nutr. Metab. Care 21, 200-206 (2018).

15. Bzikowska-Jura, A. et al. Maternal nutrition and body composition during breastfeeding: Association with human milk composition. Nutrients 10, 1379 (2018).

16. Nahrowi, N. S. Keragaman kandungan asam lemak esensial asi dan tingkat kecukupannya pada bayi di indonesia. (Institut Pertanian Bogor, 2015).

17. Segura, S. A., Ansótegui, J. A. \& Marta DíazGómez, N. The importance of maternal nutrition during breastfeeding: Do breastfeeding mothers need nutritional supplements? An. Pediatr. 84, 347.e1-347.e7 (2016).

18. Aumeistere, L., Ciproviča, I., Zavadska, D. \& Volkovs, V. Fish intake reflects on DHA level in breast milk among lactating women in Latvia. Int. Breastfeed. J. 13, (2018).

19. Nishimura, R. Y., De Castro, G. S. F., Jordão, A. A. \& Sartorelli, D. S. Breast milk fatty acid composition of women living far from the coastal area in Brazil. J. Pediatr. (Rio. J). 89, 263-268 (2013).

20. Kim, H. et al. Breast milk fatty acid composition and fatty acid intake of lactating mothers in South Korea. Br. J. Nutr. 117, 556-561 (2017).

21. Yustiani. Asupan dan Status Asam Lemak Tak Jenuh Ganda pada Ibu Hamil Kaitannya dengan Status Gizi Bayi Baru Lahir dan ASI di Kota Bogor. (Institut Pertanian Bogor, 2019).

22. Badan Pengawasan Keuangan dan Pembangunan. Peraturan Pemerintah Republik Indonesia No. 47 Tahun 2008. (2008).

23. Badan Pusat Statistik. Berita Resmi Statistik: Profil Kemiskinan di Indonesia Maret 2019. (2019).

24. Departemen Kesehatan RI. Pedoman praktis memantau status gizi orang dewasa. (Departemen Kesehatan RI, 1994).

25. Kementerian Kesehatan RI. Buku Saku Pelayanan Kesehatan Neonatal Esensial. (Kementerian Kesehatan RI, 2010).

26. Kementerian Kesehatan RI. Peraturan Menteri Kesehatan No. 28 Tahun 2019 tentang Angka Kecukupan Gizi yang Dianjurkan untuk Masyarakat Indonesia. (Kementerian Kesehatan $\mathrm{RI}, 2019)$.

27. Food and Agriculture Organization. Fats and fatty acids in human nutrition. Report of an expert consultation. FAO Food Nutr. Pap. 91, 1-166 (2010).

28. Forsyth, S., Gautier, S. \& Salem, N. Global estimates of dietary intake of docosahexaenoic acid and arachidonic acid in developing and developed countries. Ann. Nutr. Metab. 68, 258267 (2016)

29. Sulaeman, A; Hardinsyah; Setiawan, B; Mulyani, R. Kandungan Asam Lemak Pangan Indonesia. (2015).

30. Food Standard Australia and New Zealand. NUTTAB 2010 https://www.foodstandards.gov.au/science/mo nitoringnutrients/afcd/Pages/downloadableexc 
Food Standard Australia and New Zealand. AUSNUT 2011-13 food nutrient database. https://www.foodstandards.gov.au/science/mo nitoringnutrients/ausnut/ausnutdatafiles/Pages /foodnutrient.aspx.

32. Patra, K., Greene, M. M., Patel, A. L. \& Meier, P. Maternal Education Level Predicts Cognitive, Language, and Motor Outcome in Preterm Infants in the Second Year of Life. Am. J. Perinatol. 33, 738-744 (2016).

33. Qian, J., Chen, T., Lu, W., Wu, S. \& Zhu, J. Breast milk macro- and micronutrient composition in lactating mothers from suburban and urban Shanghai. J. Paediatr. Child Health 46, 115-120 (2010).

34. De La Garza Puentes, A. et al. The effect of maternal obesity on breast milk fatty acids and its association with infant growth and cognitionThe PREOBE follow-up. Nutrients 11, 2154 (2019).

35. Liu, G. et al. Relationship between polyunsaturated fatty acid levels in maternal diets and human milk in the first month postpartum. J. Hum. Nutr. Diet. 29, 405-410 (2016).

36. Huffman, S. L., Harika, R. K., Eilander, A. \& Osendarp, S. J. M. Essential fats: How do they affect growth and development of infants and young children in developing countries? A literature review. Matern. Child Nutr. 7, 44-65 (2011).

37. Urwin, H. J. et al. Immune factors and fatty acid composition in human milk from river/lake, coastal and inland regions of China. Br. J. Nutr. 109, 1949-1961 (2013).

38. Floris, L. M., Stahl, B., Abrahamse-Berkeveld, M. \& Teller, I.C. Human milk fatty acid profile across lactational stages after term and preterm delivery: A pooled data analysis. Prostaglandins Leukot. Essent. Fat. Acids 156, (2020).

39. Wu, K. et al. Fatty acid positional distribution (sn2 fatty acids) and phospholipid composition in Chinese breast milk from colostrum to mature stage. Br. J. Nutr. 121, 65-73 (2019).

40. Kilari, A. S. et al. Long chain polyunsaturated fatty acids in mothers and term babies. J. Perinat. Med. 37, 513-518 (2009).

41. Kawabata, T. et al. Polyunsaturated fatty acid levels in maternal erythrocytes of japanese women during pregnancy and after childbirth. Nutrients 9, 245 (2017).

42. Ferreira, H. D. S., Xavier Júnior, A. F. S., De Assunção, M. L., Dos Santos, E. A. \& Horta, B. L. Effect of breastfeeding on head circumference of children from impoverished communities. Breastfeed. Med. 8, 294-301 (2013).

43. Nellhaus, G. Head Circumference from Birth to Eighteen Years: Practical Composite International and Interracial Graphs. 41, 106114 (1968).

44. Chang, C.-Y., Ke, D.-S. \& Chen, J.-Y. Essential fatty acids and human nutrition. Acta Neurol Taiwan 18, 231-241 (2009).

45. Michaelsen, K. F. et al. Food sources and intake of $n-6$ and $n-3$ fatty acids in low-income countries with emphasis on infants, young children (6-24 months), and pregnant and lactating women. Matern. Child Nutr. 7, 124-140 (2011).

46. Brenna, J. T. \& Lapillonne, A. Background paper on fat and fatty acid requirements during pregnancy and lactation. Ann. Nutr. Metab. 55, 97-122 (2009).

47. Catalano, P. \& Demouzon, S. H. Maternal obesity and metabolic risk to the offspring: Why lifestyle interventions may have not achieved the desired outcomes. Int. J. Obes. 39, 642-649 (2015).

48. Glaser, C., Lattka, E., Rzehak, P., Steer, C. \& Koletzko, B. Genetic variation in polyunsaturated fatty acid metabolism and its potential relevance for human development and health. Matern. Child Nutr. 7, 27-40 (2011).

49. Barrera, C. et al. The impact of maternal diet during pregnancy and lactation on the fatty acid composition of erythrocytes and breast milk of chilean women. Nutrients 10, (2018).

50. Moltó-Puigmartí, C. et al. FADS1 FADS2 gene variants modify the association between fish intake and the docosahexaenoic acid proportions in human milk. Am. J. Clin. Nutr. 91, 1368-1376 (2010).

51. Antonakou, A. et al. Erratum to: Breast milk fat concentration and fatty acid pattern during the first six months in exclusively breastfeeding Greek women (Eur J Nutr, (2013), 52, (963-973), 10.1007/s00394-012-0403-8). Eur. J. Nutr. 55, 2177 (2016).

52. Marc, I. et al. Early docosahexaenoic acid supplementation of mothers during lactation leads to high plasma concentrations in very preterm infants. J. Nutr. 141, 231-236 (2011).

53. Collins, C. T. et al. Pre- and post-term growth in pre-term infants supplemented with higher-dose DHA: A randomised controlled trial. Br. J. Nutr. 105, 1635-1643 (2011).

54. Delgado-Noguera, M. F., Calvache, J. A., Bonfill Cosp, X., Kotanidou, E. P. \& Galli-Tsinopoulou, A. Supplementation with long chain polyunsaturated fatty acids (LCPUFA) to breastfeeding mothers for improving child growth and development. Cochrane Database Syst. Rev. 2015, (2015).

55. Meldrum, S. J. et al. Determinants of DHA levels in early infancy: Differential effects of breast milk and direct fish oil supplementation. Prostaglandins Leukot. Essent. Fat. Acids 86, 233-239 (2012).

56. Makrides, M., Smithers, L. G. \& Gibson, R. A. Role of long-chain polyunsaturated fatty acids in neurodevelopment and growth. in Nestle Nutrition Workshop Series: Pediatric Program vol. 65 123-136 (Nestle Nutr Workshop Ser 
Pediatr Program, 2010).

57. Herba, C. M. et al. Breastfeeding and early brain development: The Generation R study. Matern. Child Nutr. 9, 332-349 (2013).

58. Van de Lagemaat, M., Rotteveel, J., Muskiet, F. A. J., Schaafsma, A. \& Lafeber, H. N. Post term dietary-induced changes in DHA and AA status relate to gains in weight, length, and head circumference in preterm infants. Prostaglandins Leukot. Essent. Fat. Acids 85, 311-316 (2011).

59. Heaton, A. E., Meldrum, S. J., Foster, J. K., Prescott, S. L. \& Simmer, K. Does docosahexaenoic acid supplementation in term infants enhance neurocognitive functioning in infancy? Front. Hum. Neurosci. 7, (2013).

60. Caspi, A. et al. Moderation of breastfeeding effects on the IQ by genetic variation in fatty acid metabolism. Proc. Natl. Acad. Sci. U. S. A. 104, 18860-18865 (2007).

61. Ronnenberg, A. G. et al. Low Preconception Body Mass Index Is Associated with Birth Outcome in a Prospective Cohort of Chinese Women. J. Nutr. 133, 3449-3455 (2003).

62. Voss, W., Jungmann, T., Wachtendorf, M. \& Neubauer, A. P. Long-term cognitive outcomes of extremely low-birth-weight infants: The influence of the maternal educational background. Acta Paediatr. Int. J. Paediatr. 101, 569-573 (2012). 